\title{
eLyra
}

Alberto Martins

\section{La Reina del Cerro}

Por volta de 1921 ou 22, Felipe Calpanchay

(conforme as fontes, o proprietário de um pequeno armazém

um pastor cujas lhamas costumam se espalhar por aqueles cerros

um caçador de relíquias)

encontra a 5.175 metros de altura

no Nevado de Chuscha, província de Salta, Argentina

os sinais de uma sepultura pré-colombiana.

Convoca o mineiro chileno Juan Fernández Sales

e, com dinamite, os dois explodem a montanha.

Extraem de seu interior a múmia de uma criança

e os objetos cerimoniais que compõem

seu enxoval funerário.

A cavalo, eles a transportam até a finca Tolombón

no sopé da cordilheira

onde é exposta por alguns dias.

Os habitantes de Tolombón

cercam-na de velas e oferendas

e se referem a ela como La Reina del Cerro -

a rainha daquelas serranias. 
O próspero comerciante Pedro Mendoza

colecionador de peças arqueológicas

a adquire por alguns pesos em 1922

leva-a para Cafayate

e a exibe numa das residências

mais antigas do lugar.

Cobra ingresso dos visitantes.

Certa manhã Mendoza é surpreendido

por uma comissão de moradores de Chuscha.

Estes relatam que desde que a múmia fora subtraída

as tempestades de água, vento, neve

são ininterruptas.

Rebanhos fogem apavorados pelas ladeiras

despencam encosta abaixo, arrojam-se nos precipícios

e eles mesmos, habituados àquelas alturas

agora vivem descompostos do estômago

varados por vertigens que fazem rodar a cabeça.

Em resumo: a peste apoderara-se deles

e por isso requerem a Mendoza

que lhes entregue a rainha.

Mendoza faz o contrário: no final de 1924

vende a múmia a Perfecto Bustamante

um herborista de Buenos Aires

que a deixa em exposição

na vitrine de sua loja

a Casa Bustamante, por nove anos.

Em 1935, a viúva de Bustamante

a repassa ao senhor Absjorn Pedersen

em troca de uma instalação de gás.

Engenheiro aficcionado por arqueologia 
Pedersen tem planos de fundar seu próprio museu

e guarda a múmia no sótão

onde ela permanece durante várias décadas.

No início de 1977, Amadeo Sirolli

um especialista em megafauna argentina

publica num fascículo do Club Andino del Norte

fotografias e informações sobre a múmia

que ele encontrara na casa de Pedro Mendoza

em Cafayate, 53 anos atrás.

Em março de 1977, o programa

de televisão “Más Alto que los Cóndores"

exibe no ar uma das fotografias

e pede aos telespectadores que ajudem

a localizar seu paradeiro.

Em 1985, pobre, viúvo e doente

Asbjorn Pedersen vende a múmia

a um antiquário de San Telmo

por 48 dólares.

O proprietário seguinte é

o dentista Carlos Colombano

que adquire a peça

para seu museu particular "Chavín de Huantar"

em Martinez, na Grande Buenos Aires.

Em 1991, o andinista Marcelo Scanu

ao passar pela Calle Florida

no centro da capital

reconhece na vitrine de um banco

a múmia retratada no fascículo de 1977.

A partir daí, tudo acontece com relativa rapidez.

Em 1996, o Centro para a Conservação 
do Patrimônio de Alta Montaña, de Salta organiza uma expedição e encontra o local exato de seu enterramento no maciço de Chuscha.

Em 2001, o Centro de Estudos para Políticas Aplicadas adquire o corpo o enxoval remanescente e destina recursos para os primeiros trabalhos de conservação.

Em 2006, graças ao senhor Matteo Goretti (mais tarde acusado de roubo de tesouros argentinos pré-colombianos) a múmia é doada ao Museu de Arqueologia de Alta Montanha, de Salta onde ganha uma sala especial no mezanino. Segundo os cientistas, La Reina del Cerro é uma menina de 8 anos e meio com $1,10 \mathrm{~m}$ de altura que morreu num dia qualquer entre 1400 e 1532.

Desde que ela me recebeu em dezembro de 2016 o presente e o passado parecem cada vez mais a ponta quebrada de um iceberg. 